Article

\title{
Hallowed Haunts: The National African American Museum as Sacred Space
}

\author{
Richard Newton
}

Department of Religious Studies, University of Alabama, Tuscaloosa, AL 35487, USA; rwnewton@ua.edu

Received: 31 October 2020; Accepted: 10 December 2020; Published: 13 December 2020

\begin{abstract}
This paper uses Stephen Best's None Like Us and Charles H. Long's Significations: Signs, Symbols, and Images in the Interpretation of Religion to redescribe the notion of sacred space in light of the national African American museum. After highlighting religion and the museum's mutual Romantic origins, it underscores the invisible institution of slave religion as a modern counterpoint that is harrowingly evocative of the indeterminacy of human meaning-making. The national African American museum, represented by offerings from the Smithsonian Institution and the Equal Justice Initiative, operates as a social technology for working through the tensions of history. "Hallowed Haunts" examines its function as a matrix of haunting, where a variety of multi-sensory experiences lead visitors into a participatory reckoning with the legacy of slavery, one through which they determine how to face the challenges and potential opportunities that await them. As such, the national African American museum exemplifies Long's thesis of sacred space as human centers, a metonym for the places humans visit for orientation.
\end{abstract}

Keywords: sacred space; slavery; Charles Long; signification; museums; Stephen Best; Equal Justice Initiative; National Museum of African American History and Culture; slave religion

\section{Introduction}

In the first act of the 2018 comic book film Black Panther, an African American antagonist named Erik "Killmonger" Stevens enters the "Museum of Great Britain" in order to take a precious and powerful metal, called Vibranium, that is hidden amidst a gallery of African artifacts. Vibranium is the lifeblood of the fictional nation of Wakanda, the most technologically advanced civilization on the planet. The Wakandans protect it and themselves under their unassuming appearance as subsistence farmers and ranchers (Black Panther 2018).

We watch Stevens ask an expert, a white woman drinking a hot beverage, about the provenance of various artifacts. After several identifications, Stevens turns his attention to a mining axe. She dates it to the 7th century, hesitantly locating its origins with the Fula tribe of Benin. She is taken aback when Stevens says that it was only found there by the British and that it is in fact from Wakanda. The woman scoffs when he adds that he is not only going to take the item, but do so like her ancestors did. Her confidence in the facility's security and her relative racial standing informs her disbelief. As she doubles over in stomach pain and eventual unconsciousness, we hear Stevens say, "You got all this security watching me ever since I walked in. But you ain't checking for what you put in your body." Poisoned, she falls to the ground as Killmonger "takes it off her hands" and continues the heist. Later in the film, we learn that Killmonger is actually a son of a Wakandan prince who was maligned for his dismay over Wakanda's isolationist foreign policy and indifference toward global Black subjugation.

The scene-with its meditation on race, gender, and diaspora-is representative of the acclaimed film's themes. In "Killmonger's Quandary: Notes on Religious Freedom, Identity, and Black Panther," theological philosopher Darrius D. Hills understands Killmonger as entrapped in a "struggle with the terms of his identity and the burden of living into this identity responsibly and holistically in 
ways that are liberating and not death-dealing" (Hills 2020, p. 75). Hills arrives at this by way of "Black religion," an interpretive frame "marked by the quest for and enactment of life meaning over against social and historical circumstances that demean and dehumanize Black personality and embodiment" (Hills 2020, p. 63). Given the blockbuster film's popular appeal and this initial scene's layered significations, we stand to learn something about the power of the museum in the imagining of Black religion in particular, and religion in general.

While the scene has undoubtedly spurred critical conversations about the museum as a political institution (Ragbir 2018), it also happens contemporaneously with the opening of two major museums centered on African American life-the Smithsonian Institution's National Museum of African American History and Culture (NMAAHC) and the Equal Justice Initiative's (EJI) dual-campus Legacy Museum: From Slavery to Mass Incarceration and National Memorial for Peace and Justice in Montgomery, AL. Both sites position themselves as pivotal entities for understanding Black people's experience in the American Experiment, and the public has received them as premier destinations for study and pilgrimage. More than this, as examples of a phenomenon that I call the "national African American museum," they operate as sacred spaces within the complex of signifying practices Hills associates with Black religion. Furthermore, in her ethnography of African American appeals to Yoruba practices, Velma E. Love describes how sacred spaces are less about encountering the divine than "divining the self" (Love 2012, pp. 53-56). The national African American museum mediates similar work as an ideological capitol that lays claim to Black excellence in spite of being physically located in a place with a history of marking blackness as expendable. The museum seemingly entices visitors to harness this transformative power for themselves. What might we learn about the human by examining the national African American museum as sacred space?

This essay experiments with the category of sacred space whilst conversing with currents in the history of religions, museums studies, and Black studies. It contends, first, that sacred space is better conceptualized not as a location where the wholly other has been discovered, but as a social technology from which one can signify an alternative orientation to the world. This is historically attested in the alignment of ceremonial centers with the city and the skills required to construct captivating social programs such as religion and other discourses. Second, it argues that the postmodern cultural trend known as "the new museum" relishes in the opportunity to empower visitor discovery, the kind of encounters that correspond squarely with the Romantic roots from which the museum, religion, and the Western phenomenological imagination extend. Third, it reiterates that slave religion, frequently cited as the paragon of Black religious resilience, was even more so a reminder of what literary critic Stephen Best terms the "indeterminacy" of Black positionality (Best 2018, p. 124). Having recalibrated our understanding of the invisible institution, we can register the hope and horror that comprise volatile archival and sacred spaces alike. Finally, it looks at how the NMAAHC and EJI craft sensorial experiences with the potential to haunt visitors into reckoning with the realities of Black pasts, presents, and futures.

\section{Sacred Space in Theory}

Sacred space is a fascinating designation for the historian of religions. The more skillful a construction, the more its appearance underscores its profanity for the scholar. The more seamlessly it fits into a social framework, the more work has been done to efface the rough edges of machination and imagination. The ones that convince us of their begottenness are the most dastardly made (Newton 2020, pp. 4-10).

This proposition challenges the classic Eliadean approach to sacred space as a matter of divine excess or spillage into the profane. For him, mundane sites are marked by "an irruption (sic) of the sacred that results in detaching a territory from the cosmic milieu and making it qualitatively different" (Eliade [1957] 1987, p. 26). The hype of the hierophany is the root of sacredness; its "specialness," the result of a close encounter with some otherworldly kind; an experience, at one part existential, but also fixed to a specific location (Taves 2009, pp. 28-47). However, claims to this effect beckon scholars to 
take note of the power dynamics between the human signifiers and the spatial signs used to (mis)direct our attention. An Eliadean approach fails to give credit to the creative humans to whom it is due.

Let us consider those who seek to establish the significance of the sacred in our own time. The very expectation for encounter has made the design of sacred space a problem for modern architects. According to architect Andrew Crompton, the proliferation of natively described "sacred spaces" in quotidian locales has led to a debate over how to properly constitute these places (Crompton 2013). There are positive approaches that dress the setting to accommodate the plethora of potential encounters with the divine. Then there are negative approaches, which favor stark emptiness so as to avoid partiality and in turn present a canvas for a community's myths and ritual creations. Of course, both belie a theophanic problem. For, if all this social construction is at the heart of the space's significance, what room is left-or even, necessary-for the sacred?

Veiko Anttonen puts a finer point on this by contrasting an Eliadean view with that of Elide's Finnish contemporary, the ethnographer Uno Harva (Anttonen 2007).

Harva would have understood what Eliade meant by the symbolism of the sacred, since he identified recurrent motifs in myths and rituals and explored their cultural variation. However, it would have been out of [the] question for Harva to replace social analysis by an act of phenomenological reduction and to claim that regardless of the social and historical context and differences in individual worldviews, these representations (in Eliade's terms, hierophanies) are manifestations of a panhuman religious ontology. (Anttonen 2007, p. 60)

Where Eliade saw hierophanies as something "accessible to any individual who is willing to undergo certain ordeals to obtain them (Eliade [1964] 2020, p. 107)," Harva understood small-scale societies' claims of and to the sacred as extensions of their indigenous social ordering, which in comparative terms take shape in patterns drawn by scholars (Anttonen 2007, p. 60). Anttonen builds on this observation by suggesting that attention to the spatial boundaries of the sacred provides scholars with an opportunity for understanding groups' layered approaches to social construction (Anttonen 2007, pp. 60-61).

Crompton and Anttonen surface the artisanal realities subtending sacred space, but what might we say of the way in which "sacredness" is examined? For even in the disenchanted temples and shrines scoured by the scholar, recovery frequently appears as the default mode. There is often a primeval or axial ideal to be exhumed (This could be said of the scholar's presumption as much as the devotee's). The historically minded cannot help but want the best that the past has to offer toward their present ends. I submit that this disposition to salvage already presupposes an essence to behold, a move that betrays our analytical and redescriptive efforts.

However, that does not mean that the sacred is meaningless for the scholar of religion. On the contrary, I contend that the conspicuousness of our appeals to the sacred afford us the opportunity to revisit the social physics of our spatial significations. Reading Eliade, Charles H. Long reiterates that ceremonial centers, as "symbols of the metaphysical notion of effective space," precede "the economic, political, and military structures of citied traditions" (Long [1986] 1995, p. 79). The sacred persistence of Beijing's incorporation of the Ming Dynasty's Tiananmen Square (Cf. Tiananmen, "Gate of Heavenly Peace") and Mexico City's superposition over the Aztecan city of Tenochtitlan testify to this political history. For Long, sacred spaces are "ideological" in that they invite people to participate in "long events," in which they are introduced to "a new discourse regarding the human ... seeing the past in varying rhythms, continuities, convergences and discontinuities" (Long [1986] 1995, p. 87). The psycho-social Pangea that results brings Long to represent sacred spaces as "human centers." Those familiar with Long's storied turns of phrase will catch the plurality of his meanings-human centers are spaces of social gathering and discursive constitution. Put another way, the sacred has always been in the making rather than the maker.

Recently, ethnographers of religion have come to a similar conclusion in arguing that sacred space is a technology of signification. In a previous generation, the comparativist Huston Smith gestured toward such an understanding in his interpretation of ancient Indian art and religion as 
"spiritual technologies" effective for consciousness-raising (Moyers 1996). They are yogic tools for a paradigm of training "designed to lead to integration or union. But integration of what?" Smith ultimately settled on the divine (Smith 1958, p. 30). By way of contrast, in her study of the artisanal devotional practices of Catholic men in a Brooklyn parish, Alyssa Maldonado-Estrada has shown how observations of theological transformations only scratch the surface. "In acts of devotion, maintenance, care, gift giving, and offering, people enter into relational engagements with statues and 'objects' of devotion become 'subjects' of devotion, brought into 'co-relational being' in 'moments of active relating'" (Maldonado-Estrada 2020, pp. 98-99). As such, the senses become places for engagement and enhancement; sacred spaces, for an anthropo-dynamism that facilitates the social formation of the user and the social construction of meaning.

On this point, I am intrigued by anthropologist of religion Travis Cooper's theorizing of "social architecture." He writes:

... I want to begin the process of exploring how buildings-as-technologies do not only representationally signify but also perform values through various significations by emplacing inhabitants in various ways. Buildings are technologies, and like any useful technology, are flexible assemblages of metaphors, representations, discourses, affordances, ideas, forms, and uses. As somewhat plastic technologies or rigid metaphors, buildings encompass both the level of the symbolic and the discursive as well as the so-called realized, actual, and physical. (Cooper forthcoming)

What I find compelling in Maldonado-Estrada's and Cooper's work is their recognition that humans play a pivotal part in making a space sacred, special, or ripe for phenomenological intervention. This is not to say that people lack the great expectations of meeting their so-called maker, but the creativity exercised always complicates the essentialist terms by which fate and destiny are premised. Even for those being studied, there is at least a latent acknowledgment that sacred space is prepared and invented.

This stands in contrast to the presupposition that sacred space is a matter of recovery. Sacred space is not a reconnection to a lost abundance but a "retconnection" - that is, a retroactive erection of continuity—-that we steel (and perhaps, steal) in the modern moment, the just-now (A Short History of 'Retcon' n.d.). Literary theorist Stephen Best has offered a similar theorization in his discussion of the slave archive in Black culture:

... it is a foundational paradox of the archive to shape black culture as indispensable to and yet hopelessly beyond the reach of cultural preservation and historiographical recovery. It is my intention to show that our challenge isn't to successfully recover the past so much as it is the more modest task of simply describing something that appears to be vanishing. (Best 2018, p. 87)

The archive is a human center, a maker-space to deal with the depths of the "metaleptic history" and "sense of indeterminacy" in which we have been profoundly conditioned (Best 2018, p. 124).

In this vein, I would add that "haunting," rather than "recovery," provides a more useful root metaphor for a social theory of sacred space. Horror and hope are the same in that in both, it is an unknown and impending future that makes us look back. All the while, the site for critical observation is not an essence to behold but a disposition toward reckoning with a confounding but potentially useful past. I suggest that this order of theorizing can help us avoid the occupational hazard of seeking derivative historiographic plotlines and keep us honest about the politics presaged by sacred space.

\section{Museums as Sacred: A Romantic Apologia}

Without a doubt, the idea of museums as sacred space will appear to some as unduly transgressive. In popular convention and for no shortage of scholars, it is a statement of possession (e.g., the sacred's space, the space for sacred things, holy ground) rather than a description of activity (e.g., 
consecrated space, hallowed ground). Recent currents in religious studies, museum studies, and Black studies provide compelling rationales for my provocation (Buggein et al. 2017). The sacredness of the modern museum is an extension of the institution's history and its interpretative prospects for visitors. The invention of museums and religion are coterminous if the recent commentaries are to be believed, but I would press further that their technological uses for enhancing human signification are of a kind as well.

As much as the Enlightenment prioritized a Cartesian rationality of "I think, therefore I am," considerations of Early Modern periodization provide a more complex view of the West's intellectual history (Newton 2020, pp. 12-14). Shakespeare's "to thine own self be true" becomes a quaint truism when juxtaposed to the rise of Cabinets of Curiosities. These predecessors to the museum were where intellectuals collected and classified finds from the natural and physical world. The technical ability to do this became grounds on which possessors could classify themselves as civilized and knowledgeable, in contrast to those "primitives" who simply lived amongst the world.

The museum as private collection and elite institution further amplified the fashion of world-ordering. The visit became a means through which one gains perspective on the world. The exhibit re-presentedwith authority - the world properly understood. We would do well to draw historical connections between the invention of religion and the museum by way of the establishment of both museums of religions (Orzech 2020) and museums of the religious (Roberts and Eyl 2019), for they are products of the same aforementioned history (Isnart and Cerezales 2020).

Additionally, Charles Long's thinking presents another avenue for us to traverse. He qualifies Joachim Wach's rooting of religion to an Enlightenment project by adding that it is also a Romantic one (Long [1986] 1995, pp. 75-76). The search and the quest are Schleiermachian in that they address a deep need to encounter the fullness of the universe that lies within. Regarding "the essence of religion," Schleiermacher writes:

When you have arrived there, you will find in yourselves not only the basic characteristics of what is most beautiful and vulgar, most noble and contemptible, which you have perceived in others as individual aspects of humanity. At various times not only will you discover in yourselves all the manifold levels of human powers, but all of the innumerable mixtures of different dispositions that you have intuited in the characters of others will appear to you as mere arrested moments of your own life. (Schleiermacher 2003, p. 41)

Religion is where one encounters Eliade's hierophany (Eliade [1957] 1987, pp. 155-59); the museum, his "kratophany" (Eliade [1949] 1996, p. 448). Religion is a reflective space where humans are empowered to find sideshows and spectacles that show us, for better or worse, who we could be-geniuses, savages, victors, the spoiled. While Masuzawa has typified the rise of the history of religions as a moment of "invention" (Masuzawa 2005), the tandem history of the museum brings new salience to Hans Kippenberg's characterization, "discovery" (Kippenberg 2002).

Before elaborating on what can be "found" in these human centers, we must first note that the contemporary museum has undergone changes in regard to those who visit it and what it exhibits. Museum studies scholar Seph Rodney remarks that "the new museology" features several conceptual shifts (Rodney 2019). Previously premised on expert curation for the ignorant visitor, the museum of the 21st century "is being reconceived as a personally customizable experience significantly different from the expert curator to the untrained visitor, and more oriented toward meeting the particular needs and preferences of the visitor, now regarded as a coequal partner in the venture of making a meaningful experience" (Rodney 2019, p. 9). The private space that became a public space has since become a nexus for exchange between the two. The "interpretive museum" is a transactional space replete with "object[s] of consumptive desire and ... object[s] of amateur exegesis" (Rodney 2019, p. 40). The sacred is not in the collection; it is in the processing of contents. Just as it is not the purview of the sage elite, it is neither a task left solely to curators, design firms, docents, and historians. It is incumbent upon a relationship with the visitor. 
The museum creates a synergistic effect through their combination and provides documentary evidence of the processes and results. Thematic displays offer the visitor choice, which in turn excites her capacity to control the visit, to choose her own experience. In turn, visitors see themselves as self-actualizing agents, which dovetails with and is encouraged by displays fashioned to draw visitors who are ready and willing to employ their interpretive faculties. (Rodney 2019, p. 10)

The new museology fits well with Cooper's notion of the museum as social technology, particularly in the renewed focus on human actualization and synergies. Far from being a mere destination, the museum has become a place one goes and comes out-a waypoint, a node in a circuit, a stop on the path of revolution and transformation (Howes 2017).

The new museology also buttresses Long's reflections on the engagement that takes place in the city as ceremonial center. The ontology of the kratophanic is political. However, to be sensitive to the ideological facets of the museum is not to insist on disembodiment-quite the contrary. The role of the senses, as sites of signification, make the interpretive museum a tantalizing proposition (Plate 2015; Classen 2017). As Rodney argues:

The interpretive museum, which is focused on facilitating the personal selection of interpretive experience by the visitor figure though engaging her sensual awareness and critical powers, and encouraging her to be active in constructing meaning out of the materials presented, is increasingly regarded as a valid rival to the museum of quiet contemplation and the museum of didactic instruction. (Rodney 2019, pp. 40-41)

Scholars of museum studies and material religion have also shown that the discourse at play in the museum is overwhelmingly sensorial. "In redirecting interest from objects used as evidence to objects that evoke experience, museums combine two contemporary cultural trends," philosopher Hilde S. Hein outlines (Hein 2000, p. 79). First is a "shift ... that turns attention from real things to real subjective states. The second tendency, which merges with the first, valorizes emotive over cognitive meaning. It identifies the experiential with the empathic, and in calling for a reality of experience, it covertly gives priority to the evocation of feeling" (Hein 2000, p. 79). "Blending sensual and narrative approaches thus offers an opportunity to create moments of productive surprise for visitors, particularly in comparative or thematic exhibits," adds historian Turek (2017, pp. 60-61). In the case of the national African American museum, we are reminded that surprise can be healing and harrowing. But why would we expect anything else when considering the sacred? It is that volatility that brings us in the orbit of human centers in the first place.

\section{The National African American Museum as Matrix of Haunting}

My foray into the NMAAHC and EJI began with a simple observation that people around me-in America, usually Americans, some of whom were Black Americans-were discussing their visits to these spaces as if they were making a pilgrimage. I heard their intentions for going and their wanting to be impressed. I listened to how they were changed and how they hoped to do their part to change the world as a result, and I sat with them when they struggled to process and even stomach the gut-wrenching realities within these spaces. These observations sparked my interest in thinking about these places as somehow sacred.

Initially I thought that, as museums, whatever significance there would have to emanate from the collections, but upon further reflection, the constitution of the sacred proved to be more complicated than these museums' possessions. Historian of religion in America Judith Weisenfeld points out how the curation of religion in the NMAAHC leaves something to be desired. "The museum's interpretive frame as represented in text panels accompanying objects on display is often less compelling than the powerful artifacts demand. There are numerous panels throughout the museum with headings like 'The Church,' 'Religion,' 'The Black Church,' 'The Role of the African-American Church'” (Weisenfeld 2017). To be certain, the visitors I met held in high esteem and even revered the contents of these spaces, but 
they all but sublimated the significance of any particular object into the broader import of the museum space. Similarly, word of mouth made me aware of many of the EJI's exhibits before I visited myself. However, no one ever insisted that I be sure to see a specific object-rather I was to go to the EJI for the experience. One simply had to be there to understand.

My visits did not disappoint. In contrast to the untapped or less-signified potential of any given artifact, the NMAAHC and the EJI are reminiscent of what Weisenfeld has elsewhere termed "the shadow maps" of Black sacred space.

Black people have produced and navigated shadow maps from the moment they were forced onto North American shores and into the expanding system of racial slavery. They forged connections with one another across spaces of captivity by creating pathways to avoid white patrollers, and they used the night sky as a guide to map routes to free themselves from enslavement. (Weisenfeld 2020)

The national African American museum's sacredness is its work as an immersive shadow map. Visitors explore the histories and orientations that will make them more fit to navigate the world. It is an exercise in ascetic sacrifice where participants subject themselves to an assault of the senses in exchange for an agency that can be stored up and drawn upon in moments of uncertainty. The context of these spaces within their respective cities (Washington DC and Montgomery) and their ideological pretexts (hopeful and horrific, respectively) situate visitors within a matrix of haunting where they are guided through fright as a means of preparing for the less-scripted challenges outside the museum.

By way of comparison, the national African American museum is like a museum of and to religion. Like a museum of world religion, it is a full-fledged educational institution. Similar to the Museum of the Bible in Washington DC, it is a pilgrimage site for empathetic appreciation for a heritage-one to a chosen people, often rendered in supersessionist "Judeo-Christian" terms (Hicks-Keeton and Concannon 2019; Young 2019, pp. 25-41); the other, to the human and civil rights of Black people. Furthermore, like many of the museums of biblical lands, it places visitors in large-scale panoramas. That is, as new museums, they are not so rigid as to send one on a single path, but there is ample opportunity to lose oneself in wonderment. However, there is a key difference.

All of the history presented in the national African American museum happens in the shadow of slavery. There can be no arrogation of intrinsic genius because of the devastating dehumanization of the people described. In its place is an expression of resilience. In place of myths of persecution (a subtext of much of the Christian cases), there is documentation of annihilation, extermination, and a foreboding reality that it may not be over in light of a present struggle. A just, poignant, and perhaps more obvious parallel in the history of religions is the Holocaust museum-a site that does not function as an ode to the Shoah but a Jacobean wrestling with it, and the re-membering that follows. One leaves never able to forget.

In a Longian application of the category "sacred" to the national African American museum, we prepare ourselves to observe a polarity between two symbolic loci: "Africa," less as place but "historical reality and religious image," and "slavery" or "the involuntary presence of the black community in America." Additionally the polarity comes with a charge or valence further signified in "the experience and symbol of God in the religious experience of blacks," which happens at both (Long [1986] 1995, p. 188). Long first introduced his intervention, "Perspectives for a Afro-American Study of Religion," in a 1971 issue of History of Religions, and it can continue to help us today to account for "religious experience" as an example of the historical negotiations and ideological exchanges that occur at human centers-sacred spaces, the city, the museum, and beyond.

Historiographic recalibrations of "slave religion" can sharpen our understanding of how sacredness operates. The national African American museum is akin to Albert J. Raboteau's discussion of "the invisible institution" (Raboteau [1978] 2004). Writing about the Christianity of the enslaved, Raboteau posits: 
The religious experience of the slave was by no means fully contained in the visible structure of the institutional church. From the abundant testimony of fugitive and freed slaves it is clear that the slave community had an extensive religious life of its own, hidden from the eyes of the master. In the secrecy of the quarters for the seclusion of the brush arbors ("hush harbors") the slaves made Christianity truly their own. (Raboteau [1978] 2004, p. 212)

Raboteau assigns almost-celebratory agency to the people and power to the events that took place in those hidden meetings.

Stephen Best might challenge Raboteau, however, to reconsider if only for a moment, the terms on which the sacred is defined. The juxtaposition of the "brush arbors ('hush harbors')" makes the sacred an essence to behold, here or there, and a foregone conclusion, as if power is in ever-presence. However, Raboteau's "invisible institution" is a heuristic that Best calls, a "rumor in the archive: an appearance made possible only in its disappearance; an aspiration registered at the moment of its suppression; a power that reaffirms itself by liquidating its sources." (Best 2018, p. 123) Raboteau's thesis comes from an "abundant testimony" that appears more confident than the events that provided it. Raboteau himself contrasts the "morally sanctioned enjoyments" of the outdoor celebrations where even white onlookers would be enraptured with the moments when the enslaved would "steal away" from the gaze of white overseers in an effort to avoid the policing of their expressions (Raboteau [1978] 2004, pp. 220-22).

With all due respect to the work of Raboteau, to conflate the former and the latter could lead us to miss how the occasion for stealing away is indicative of an "indeterminacy" that the notion of the archive-and those who visit it—replace with certainty (Best 2018, p. 123). Were we to do this, we might overlook important lessons about the constitution of the sacred. Historian Alexis S. Wells-Oghoghomeh poignantly distinguishes the moods of the hush harbor and the brush arbor.

Indeed, most of the theologies, performances, and songs that rendered African American Christian religiosity distinctive emerged outside of the sanctioned spaces of religious edifices. Brush arbors, partially or fully open air constructions hewn out of tree brush and used for religious exercises by southern blacks and whites, as well as hush harbors-the cabins, clearings, and other spaces that the enslaved designated for religious gatherings away from white surveillance-served as incubators for enslaved African Americans' religious narratives, theologies, and rituals. (Wells-Oghoghomeh 2019, p. 27)

Wells-Oghoghomeh's diction — the "hewn" brush arbor and the "designated" hush harbor-are distinguished by a symbolic public permanence under the gaze of white folk and a recognized private transience hidden from them. Part of what makes her comparison of "incubators" a welcome intervention is the mutual recognition of its parameters, mirroring the "the fragile status of the enslaved-an expression of their political, even existential, uncertainty" and its amplification of the agency employed (Best 2018, p. 123).

This is the power latent in the invisible institution of human centers like the brush arbor, the hush arbor, and as we will see, the national African American museum. In all three haunts, Black people face tensions that will equip them to face the chaos and cosmos outside. Their sacredness is not in their coordination with the axis mundi. It is in their reflection of people's cartographic potential for categorizing, classifying, identifying, ordering, and organizing social realities. The national African American museum reminds us to observe how the city and the senses provide opportunities for human-centering significations.

\section{Haunting Significations at Two National African American Museums}

The following section presents two national African American museums as case studies in the fabrication of the sacred. Again, sacredness here signifies each site as a technology in which the visitor enters a matrix of haunting to both face and embrace the indeterminacy of the social conditions that gave rise to each institution. Each site, as an example of a new museum, is understood as providing 
sensorial opportunities for visitors to curate a past that will inspire and equip them to reengage the present beyond the museum.

My examination is the result of my own reflections and observations on visits to both sites in their early years-the NMAAHC in 2018 and 2019 and the EJI in 2020-and the guiding literature both have produced (Conwill 2016; Wilson 2016; Kendrick 2017; Equal Justice Initiative 2018a, 2018b). In due time, scholars will produce thicker descriptive analyses of both spaces, but the following notes and preliminary interpretations permit us to resist the expert opinions that sequester intrigue to the well-disciplined. In these nascent moments, we can still yet attune ourselves to the whispers about the significatory potentialities and the rumors in the archive. Thus, what I present below are just some of the interpretive possibilities one might find in these spaces given due attention to senses and human centers.

Furthermore, I present the data for this study in analogical terms. Comparison is the methodology of choice here because it helps us resist the genealogical conundrum that mystifies our understanding of discourses like sacred space (Smith 1990, p. 51). The NMAAHC and the EJI together serve as exemplary refractions of the phantasm to which I intend to give shape. The selection of my examples-like those housed in the museum - are not freely given. They are not innocent but especially interest-serving (Lincoln 2018, p. 25; Smith 1990, p. 51). I suspect these two institutions, among other museums of the African American experience, stand out to me because of their location in cities that, together, accentuate answers to the question of whether Black lives matter in America. The heuristic construct of the national African American museum - and its hallowed haunts-are the focus of interest because they showcase the relationship between what we already suspect and what we shutter to remember about the human condition-that our histories are the product of burials and monuments alike.

I will begin by (a) framing each museum in light of the cultural complex that we have referenced as "the city," paying mind to the way in which the locations of these sites position the visitor into specific hermeneutical contexts for their consideration. I will then shift toward discussions of each space by highlighting what visitors may (b) perceive [cf. sight], (c) intake [cf. taste and smell], as well as (d) examine [cf. touch and hear]. The sensory groupings that accompany these modalities are both a gesture toward synesthetic qualities of human signification as well as a gesture toward the politics of agency in the space. Museums generally present themselves as primarily optical spaces, so the section on perception focuses specifically on sight. Taste and smell represent intimate, internalizing sensations that are only recently becoming a matter of curatorial interest with the rise of the new museum and the shift of interpretive authority increasingly favoring the visitor. Similarly, the tactile and the aural have received more attention in the museum and are taken as useful for dispelling docetic illusions for the curator and visitor alike.

Through this comparison, I hope to offer a critical vision of the national African American Museum as sacred space. However, as should be clear, my interest is not in proving the religiousness of these sites or registering their success at transforming people's lives. Rather, what I think demands more of our attention is the participatory reckoning that occurs at each site, the push to desire more from the world and ourselves. That is what constitutes a notion of the sacred that has meaning.

\subsection{The City}

The national African American museum involves many categorical and, more specifically, geographical paradoxes through which the visitor can explore the bounds of meaning. Like all sacred spaces, it is a product of its context and also being out of place. It occupies a tension designed to hold a preexisting attention while provoking a new response. The cities that house its exemplars were already important but are now even more so because of the museums. In our noting their mutual residence in capitols tied to opposing sides in the Civil War, we can begin to approach the national African American museum as a space of myriad significations rather than monolithic importance. At the same time we should observe that their opposing polarity are accidents of a similar force- the hermeneutical impulse to make the past work. 
The NMAAHC is located on the Washington Mall in Washington D.C. Around it are other museums of the Smithsonian Institution, national monuments, government office buildings, and commercial buildings like the Trump Hotel. All are basking in the privilege of being situated near the seat of national power. Many promotional photos capture a perspective that accentuates the white Washington Monument obelisk's proximity to the NMAAHC's three-tiered bronze lattice corona. Yet, historians and curators of the museum have been quick to remind visitors that this centering was a labor that required the patience of Job. In 1915, fifty years after the Civil War, Black Americans began to organize an effort to commemorate the contributions and critiques of "Colored Citizens," some of whom had fought in the war and then Jim Crow. It took a century to convince government officials to prioritize and execute the idea of a national museum devoted to the legacy of African Americans. Design firm The Freelon Adjaye Bond/SmithGroup worked to weave this multi-generational diasporic struggle into the very architecture of the museum.

From one perspective, the building's architecture follows classical Greco-Roman form in its use of a base and shaft, topped by a capital or corona. For our Museum, the corona is inspired by the three-tiered crowns used in Yoruban art from West Africa. Moreover, the building's main entrance is a welcoming porch, which has architectural roots in Africa and throughout the African Diaspora, especially the American South and Caribbean. Finally, by wrapping the entire building in an ornamental bronze-colored metal lattice, Adjaye pays homage to the intricate ironwork crafted by enslaved African Americans in Louisiana, South Carolina, and elsewhere. (The Building n.d.)

For all of the ceremony that can (and does) enshrine a site of this kind, the business of the city is not wholly out of view. Despite their labor in transporting, feeding, and outfitting visitors in the museum's perimeter, many of the members of D.C.'s majority-Black population who facilitated my visit had yet to actually enter the space. The ethics of cultural exchange come further into view as visitors descend into the museum's subterranean Concourse and History Galleries. Beside the escalator, one can see out the window the neoclassical U.S. Department of Commerce and read its architecture parlante:

The inspiration that guided our forefathers led them to secure above all things the unity of our country. We rest upon government by consent of the governed and the political order of the United States as the expression of a patriotic ideal which welds together all the elements of our national energy promoting the organization that fosters individual initiative. Within this edifice are established agencies that have been created to buttress the life of the people, to clarify their problems and coordinate their resources, seeking to lighten burdens without lessening the responsibility of the citizen. In serving one and all they are dedicated to the purpose of the founders and to the highest hopes of the future with their local administration given to the integrity and welfare of the nation.

At the end of the escalator is an elevator that leads visitors to the bottom of the three-floor History Galleries. The elevator attendant explains that this elevator takes people back through time: "Slavery and Freedom: 1400-1877," "Defending Freedom, Defining Freedom: The Era of Segregation 1877-1968," and "A Changing America: 1968 and Beyond." In addition to learning about the museum's layout, the attendant instructs people about the waiting times and etiquette for viewing the original casket of Emmett Till and that there is no exit betwixt the galleries. Visitors can only take their leave by "rising" through the levels, a keyword in the attendants narration. Once they rise back to the main concourse, they are then free to explore the rest of the museum's exhibits and spaces, the gift shop, or building exit. The way back to the agency, volition, and, literally, commerce that many associate with the city is through the architecture of the museum. Life, liberty, and the pursuit of happiness require a reorientation to US history, especially the realities that come with understanding story of a place where people were property.

The EJI is located in Montgomery, AL, a city with an ideological significance no less tortured than Washington D.C. As indicated by its Great Seal, Montgomery presents itself officially as "the Cradle 
of the Confederacy" (of which it was the initial capitol in 1861 until it moved to Richmond, VA later that year) and the "Birthplace of the Civil Rights Movement." The latter appellation is justified by the Montgomery Bus Boycott, the Bloody Sunday massacre, and other memorialized events. The dual appeal to origins presents a backdrop for the writing of a dramatic revolutionary history.

Case in point, Montgomery is also the geographical site where civil rights attorney Bryan Stevenson leads an effort to argue the connection between de facto slavery and de jure slavery. To him, the evolution of chattel slavery to sharecropping and the convict-lease system maps squarely on to the present institutions of mass incarceration and the finality of the death penalty. While the public square debates the usefulness of elaborations on "Black bodies" in elaborating on the politics of Black existence, Stevenson's project makes clear that understanding how the currency works is central to making the phrase obsolete (Aysla 2020). "The opposite of poverty is not wealth; the opposite is justice," one EJI donation card proclaims. In arguing a psychological, sociological, and economic link between these institutions, the Equal Justice Initiative historicizes lynching as the ultimate indictment on a country that proclaims itself to be the land of the free and the home of the brave.

As previously mentioned, the EJI lays out its thesis at two sites. The Legacy Museum: From Enslavement to Mass Incarceration is situated inside a warehouse downtown where enslaved persons were held, roughly equidistant from a railroad station, river dock, and city auction block, all of which served as means of transportation to exchange Black people for money. The National Memorial for Peace and Justice is in a grove about a mile away. It possesses outdoor sculptures of enslaved Africans. Pendent from an open air somber pavilion are 800 corten steel monuments for each county where EJI has confirmed the lynching of Black persons-the names of the slain inscribed on each respectively. Rods suspend the gravestones as if to replace swinging ropes and corpses with a stated dignity. Across the street an indoor multimedia facility resounds with calls to dismantle the all iterations of racist and death-dealing bonds. Despite EJI's own mission to end the illegalities, injustices, and abuses of the criminal justice system in pursuit of true civil rights, only the most sobering optimism can elude this space's gravity. As much is conveyed on a wall just outside of the Legacy Museum by way of reference to Maya Angelou's "On the Pulse of Morning": "History, despite its wrenching pain, cannot be unlived, but if faced with courage, need not be lived again."

Washington D.C. and Montgomery, AL, locate visitors in sites with a history of human centering. The NMAAHC and EJI are storied halls that echo the anti-Black challenges of the broader world while also extending a program for dealing with them. To this very point, both institutions draw upon the words of Ida B. Wells-Barnett to express this, "The way to right wrongs is to turn the light of truth upon them." What is fascinating is that they both beckon visitors to shroud themselves so as to train them to adjust, adapt, and ultimately leave to address the challenges that await. In the matrix of haunting the intrigue of the senses serves to equip visitors accordingly.

\subsection{Sensorial Significations}

\subsubsection{Perception}

The national African American Museum manipulates the shadows and veil cast by the color line. It becomes a space that, in DuBoisian understanding, projects more than a curiosity about the problem of being Black in America. It fathoms, ponders, and envisions the absent scenes where the power to endure must reside, for otherwise the present would not be. This is a space to imagine what the dead would make apparent if they could. Each museum creates conditions for the living to reflect upon what visitors will do since they too could have been an exhibit were the accidents of history only slightly modified.

At the beginning of the Legacy Museum, visitors encounter holographic projections of enslaved persons emoting and testifying to the Hell through which they are living. We look through iron bars to see them with just enough context to know that they are human like us but caught in a system that has done everything possible to render them otherwise. They do not exist in a diorama of beating or sale. They are imprisoned there waiting, existing as something qualitatively different, soon to move for 
someone else's benefit. And yet, as we peer at them, they remain there for our benefit, to convict us to be and act differently.

A similar conceit happens at the NMAAHC, but not in its employ of illusory fabrication but in the staging of artifacts. The possessions and touched-stones of the dead linger in the afterlife for those who desire to construct memories. For me the rumor in the archive was the trio of Black women, roughly 70 years in age, who walked just ahead of me during one trip to the NMAAHC. I saw them peer through a shard of stained glass from Birmingham's 16th Street Baptist Church. They looked on and said the names of Denise McNair, Addie Mae Collins, Cynthia Wesley, and Carole Robertson while also remembering how they too were going to church that morning. Later I saw one of the women let the others know that she needed to see Malcolm X's personal effects and "pay her respects." Commentary ex tempore mediated the divide between the fading past and the impression of progress, not with fate but with inventory, an accounting of the cost.

The haunting at the national African American museum is ever-present in the sense that both museums go to great lengths to detail how the violence-understood as regrettably central to the unfolding narrative- has taken place nearly everywhere in the United States. There are detailed maps, numerous state historical markers, photographs, and textual excerpts that chronicle how and why no place can claim innocence in the nation's horrid story. Nevertheless, this also comes with the possibility that every place can know justice if those visiting can make resolution and revolution their charge to keep.

\subsubsection{Intake}

In academic and public appraisals, museums primarily operate as educational institutions. At the same time, a key facet of the museum as sacred space is the way in which visitors engage by way of intinction. In Christian argot, the experience is not only evangelical or kerygmatic, but also sacramental and liturgical (cf. Gk. Leitourgia, the work of/for the people). The two examples of the national African American Museum foster reflection and provide sustenance albeit through contrasting means.

Beyond its service as an entry to and exit from the History Galleries, the NMAAHC Concourse provides two mainstays that envigor the sojourner whichever way they are going. The Contemplative Court is a square room where a font of water falls into a pool illuminated by a ring of light from above. There, an aromatic smell engulfs the room as onlookers reflect on the experience before or behind them. It is a cleansing contrast to the troubles of the city beyond the walls. The NMAAHC Concourse also includes a restaurant called the "Sweet Home Cafe." It specializes in African American and Black Atlantic cuisine. Some visitors eat after making their way to the museum; some, prior to leaving. What is of interest to me here is how the strength imparted by the food serves a similar function to the Interactive Lunch Counter on the second floor of the History Galleries. True to life, no food is offered at this simulation of the Greensboro Sit-Ins. Instead, those at the counter take in scenes of the Civil Rights Movement as they stream across massive LED screens. The counters dish the written and unwritten transcript that protestors used to transform hunger into social change.

The EJI taps into a similar vibe but with a negative approach to consumption. There is no aromatic cleansing pool in the Legacy Museum. Visitors volunteer to be temporarily trapped in the former warehouse, subject to the stench of enclosure and an arguably stagnant history of anti-Black injustice. The outdoor National Memorial for Peace and Justice presents a much-welcome, dare I say eucharistic (cf. Gk. eucharisto, thankful, welcome) ventilation. But even this is weighted by the reality that there is no escape from the violent moment at hand. The shadows cast by statues of enslaved Africans indicate a delayed dawn, and at the sides of the memorial proper are ebony walls with water streaming down heavy with grief. Visitors are left to determine for themselves what they can bear and will do to bring and find salvation, yes, to themselves, but also to those who thirst for it the most.

\subsubsection{Examination}

In application of the new museum sensibility, the national African American museum emphasizes interactivity toward the ends of participatory reckoning. Touch and hearing allow for a palpable 
experience of each museum's agendas. The significations there move visitors to examine the indeterminate, subjunctive mood of Blackness as it plays out in America. Once again, contrast communicates as much about the dynamics as commonality.

The NMAAHC and the EJI layout slavery as an origin for the present situation in kratophanic terms. That is to say the national African American museum acknowledges the institution as catastrophically defining for (but not determinative of) the narrative. Both of our examples seemingly start there. I speak gnostically here because though they initiate the timeline with the Transatlantic Slave Trade, they communicate to visitors something more, a journey to freedom. The NMAAHC ends with a call to study freedom's reach and limits; the EJI, its presence and absence. People come to the space for a reason and must work through a gripping history to leave.

Someone moving through the NMAAHC's History Galleries may feel the regret or shame that comes with seeing the thousands of encased artifacts and not being able to touch them or hearing an exhibit's audio commentary at a clip too overwhelming to fully grasp. However, there are key moments where these restrictions are loosened, bringing a hermeneutical liberation in the telling of the story. For instance, on a level called Explore More!, which sits atop the ground floor's Heritage Hall, the African American dance company, Step Afrika!, digitally appears to invite visitors to join in a step routine which they walk them through. Two floors above, in the Culture Galleries, is an exhibit called Musical Crossroads. Participants can visit a neighborhood record store and select album covers coded to play the hits from the genres in which African Americans have left an indelible mark. On numerous occasions, I have witnessed traditions illustrative of the DuBoisian "frenzy" and Durkheim's "collective effervescence" as the people gathered sing and dance along to their favorite tunes playing on the speakers overhead.

Perhaps the national African American museum can conjure no starker an experience than the veil erected at EJI. In the Legacy Museum there are booths in imitation of those where one can visit an incarcerated person. The cold seats and telephone provide the altar where one hangs onto the every word of one who knows what it means to not be free. A person on a screen speaks their truth with sighs and groans too deep for words. The National Memorial for Peace and Justice has visitors connect this to the blood that cries out from the ground. At the memorial's indoor facility, there is a wall lined with hundreds of jars of soil, each collected from the ground where a Black person was lynched in the United States of America. Collected as part of EJI's Community Remembrance Project, visitors can only vicariously touch the soil by reading the names, places, and dates on the jars; their hands, presumably free to till a future where history does not repeat itself.

\section{Conclusions}

As sacred space, the national African American museum illustrates how human beings are not the masters of their own fate. Visitors, like all of us, are subject to forces and conditions not of our own making. They are awash in a sea of indeterminacy where the slightest difference can amount to life or death, freedom or bondage, cosmos or chaos. Nevertheless, when we refuse these truths to be self-evident, we can visit matrices of haunting to be startled, shaken into reckoning. The national African American museum haunts those inside that they may know and remember what the world is, potentially full of signs to be signified by a signifier.

After all, the national African American museum was created from something. In the city, we see humans' penchant for living by proxy and how there can be utility in escape, even into a space that colonizes conscience and assaults the senses. The value is that it prepares us for a capacity to divine the self. Like the brush harbor and hush harbor before it, we go to designate and hewn a world that will accept us because the one where we reside, as is, does not.

In days to come, I have no doubt that scholars will bring heavy pens and volumes of learning to comprehend the NMAAHC and EJI. They could and should do so with other sites as well. It is my hope that they do so in remembering the subtext of Killmonger's admonition-to be on the lookout for what these institutions put in our bodies, what they are doing with our senses. The sacred spaces to be 
studied are human centers and how they orient and disorient us into seeing what is not there and what could be. Hallowed be their name.

Funding: This research received no external funding.

Conflicts of Interest: The author declares no conflict of interest.

\section{References}

A Short History of 'Retcon'. n.d. Merriam-Webster Words We're Watching. Available online: https://www. merriam-webster.com/words-at-play/retcon-history-and-meaning (accessed on 30 October 2020).

Anttonen, Veiko. 2007. Rethinking 'Religious' Cognition: The Eliadean Notion of the Sacred in the Light of the Legacy of Uno Harva. Temenos 43: 53-72. [CrossRef]

Aysla, C. 2020. Can We Stop Referring to Black People as 'Black Bodies?'. Medium. October 14. Available online: https:/ medium.com/age-of-awareness/can-we-stop-referring-to-black-people-as-black-bodies-a1f636d27658 (accessed on 30 October 2020).

Best, Stephen. 2018. None Like Us: Blackness, Belonging, Aesthetic Life. Durham: Duke University Press, ISBN 978-1-4780-0150-8.

Black Panther. 2018. Directed by Ryan Coogler. Burbank: Marvel Studios.

Buggein, Gretchen, Crispin Paine, and S. Brent Plate, eds. 2017. Religion in Museums: Global and Multidisciplinary Perspectives. New York: Bloomsbury, ISBN 978-1-4742-5551-6.

Classen, Constance. 2017. The Museum of the Senses: Experiencing Art and Collections. New York: Bloomsbury, ISBN 9781474253796.

Conwill, Kinshasha Holman. 2016. Dream A World ANew: The African American Experience and the Shaping of America. In Association with the National Museum of African American History and Culture. Washington: Smithsonian Books, ISBN 978-1-58834-568-4.

Cooper, Travis Warren. forthcoming. Spatial Hierarchy and Religious Distinction in an Architectural Utopia. In American Examples. Edited by Michael J. Altman. Tuscaloosa: University of Alabama Press, vol 1.

Crompton, Andrew. 2013. The Architecture of Multifaith Spaces: God Leaves the Building. The Journal of Architecture 18: 474-496. [CrossRef]

Eliade, Mircea. 1996. Patterns in Comparative Religion. Translated by Rosemary Sheed. Lincoln: University of Nebraska Press, ISBN 978-0-8032-6733-6. First published 1949.

Eliade, Mircea. 1987. The Sacred and Profane: The Nature of Religion. Translated by Willard R. Trask. New York: Harcourt, ISBN 978-0-15-679201-1. First published 1957.

Eliade, Mircea. 2020. Shamanism. Translated by Willard R. Trask. New York: Harcourt, ISBN 978-0-691-21066-7. First published 1964.

Equal Justice Initiative. 2018a. Living Legacy: Voices from Lynching in America. Montgomery: Equal Justice Initiative. Equal Justice Initiative. 2018b. The National Memorial for Peace and Justice. Montgomery: Equal Justice Initiative.

Hein, Hilde S. 2000. The Museum in Transition: A Philosophical Perspective. Washington: Smithsonian Institution Press, ISBN 1-56098-371-X.

Hicks-Keeton, Jill, and Cavon Concannon, eds. 2019. The Museum of the Bible: A Critical Introduction. Lanham: Lexington Books/Fortress Press, ISBN 978-1-9787-0282-0.

Hills, Darrius D. 2020. Killmonger's Quandry: Notes on Religious Meaning, Freedom, and Identity in Black Panther. Journal of Africana Religions 8: 62-83. [CrossRef]

Howes, Graham. 2017. Transactional and Experiential Responses to Religious Objects. In Religion in Museums: Global and Multidisciplinary Perspectives. Edited by Gretchen Buggein, Crispin Paine and S. Brent Plate. New York: Bloomsbury, pp. 93-98. ISBN 978-1-4742-5551-6.

Isnart, Cyril, and Nathalie Cerezales, eds. 2020. The Religious Heritage Complex: Legacy, Conservation, and Christianity. London: Bloomsbury, ISBN 978-1-350-07251-0.

Kendrick, Kathleen M. 2017. Official Guide to the Smithsonian; National Museum of African American History E Culture. Washington: Smithsonian Books, ISBN 978-1-58834-593-6.

Kippenberg, Hans G. 2002. Discovering Religious History in the Modern Age. Princeton: Princeton University Press, ISBN 0-691-00909-0. 
Lincoln, Bruce. 2018. Apples and Origins: Explorations in, on, and with Comparison. Chicago: The University of Chicago Press, ISBN 978-0-226-56407-4.

Long, Charles H. 1995. Significations: Signs, Symbols, and Images in the Interpretation of Religion. Aurora: The Davies Group, ISBN 1-888570-51-2. First published 1986.

Love, Velma E. Love. 2012. Divining the Self: A Study in Yoruba Myth and Human Consciousness. University Park: Penn State University Press, ISBN 978-0-271-05405-6.

Maldonado-Estrada, Alyssa. 2020. Lifeblood of the Parish: Men and Catholic Devotion in Williamsburg Brooklyn. New York: NYU Press, ISBN 978-1-4798-3049-7.

Masuzawa, Tomoko. 2005. The Invention of World Religions: Or, How European Universalism Was Preserved in the Language of Pluralism. Chicago: The University of Chicago Press, ISBN 0-226-50989-3.

Moyers, Bill. 1996. The Wisdom of Faith with Huston Smith: A Personal Philosophy. Moyers on Democracy. April 23. Available online: https://billmoyers.com/content/a-personal-philosophy-the-wisdom-of-faith-withhuston-smith/ (accessed on 11 December 2020).

Newton, Richard W., Jr. 2020. Identifying Roots: Alex Haley and the Anthropology of Scriptures. Sheffield: Equinox, ISBN 978-1-7817-9546-0.

Orzech, Charles D. 2020. Museums of World Religions: Displaying the Divine, Shaping Cultures. London: Bloomsbury, ISBN 978-1-350-01624-8.

Plate, S. Brent. 2015. A History of Religion in $5 \frac{1}{2}$ Objects: Bringing the Spiritual to Its Senses. Boston: Beacon Press, ISBN 9780807036709.

Raboteau, Albert J. 2004. Slave Religion: "The Invisible Institution" in the Antebellum South, Updated ed. New York: Oxford University Press, ISBN 0-19-517412-7. First published 1978.

Ragbir, Lisa. 2018. What Black Panther Gets Right about the Politics of the Museums. Hyperallergic. March 20. Available online: https://hyperallergic.com/433650/black-panther-museum-politics/ (accessed on 28 October 2020).

Roberts, Erin, and Jennifer Eyl, eds. 2019. Christian Tourist Attractions, Mythmaking, and Identity Formation. London: Bloomsbury, ISBN 978-1-350-16469-7.

Rodney, Seph. 2019. The Personalization of the Museum Visit: Art Museums, Discourse, and Visitors. New York: Routledge, ISBN 978-1-138-04582-8.

Schleiermacher, Friedrich. 2003. On the Essence of Religion [1799]. In On Religion: Speeches to Its Cultured Despisers, 2nd ed. Translated and Edited by Richard Crouter. New York: Cambridge University Press, ISBN 0-521-47448-5.

Smith, Huston. 1958. The Religions of Man. New York: Harper \& Row, ISBN 978-0-0608-0021-5.

Smith, Jonathan Z. 1990. Drudgery Divine: On the Comparison of Early Christianities and the Religions of Late Antiquity. Chicago: The University of Chicago Press, ISBN 0-226-76363-3.

Taves, Ann. 2009. Religious Experience Reconsidered: A Building Black Approach to the Study of Religion and Other Special Things. Princeton: Princeton University Press, ISBN 978-1-4008-3097-8.

The Building. n.d. The National Museum of African American History and Culture. Smithsonian Institution. Available online: https://nmaahc.si.edu/explore/building (accessed on 30 October 2020).

Turek, Lauren F. 2017. Religious History Objects in Museums. In Religion in Museums: Global and Multidisciplinary Perspectives. Edited by Gretchen Buggein, Crispin Paine and S. Brent Plate. New York: Bloomsbury, pp. 57-62. ISBN 978-1-4742-5551-6.

Weisenfeld, Judith. 2017. Religion on Display at the National Museum of African American History and Culture. Sacred Matters: Religious Currents in Culture. January 3. Available online: https://sacredmattersmagazine. $\mathrm{com} /$ religion-on-display-at-the-national-museum-of-african-american-history-and-culture/ (accessed on 5 December 2020).

Weisenfeld, Judith. 2020. Space, Place. The Immanent Frame. February 28. Available online: https://sacredmattersmagazine.com/religion-on-display-at-the-national-museum-of-african-americanhistory-and-culture/ (accessed on 5 December 2020).

Wells-Oghoghomeh, Alexis S. 2019. Re-evaluating Roots: Slavery as Source and Challenge for African American Theology. In TET CLARK Handbook for African American Theology. Edited by Antonia Michelle Daymond, Frederick L. Ware and Eric Lewis Williams. New York: Bloomsbury, pp. 19-32. ISBN 978-0-5676-7544-6.

Wilson, Mabel O. 2016. Begin with the Past: Building the National Museum of Africa American History and Culture. Washington: Smithsonian Books, ISBN 978-1-588344-569-1. 
Young, Stephen L. 2019. The Museum of the Bible: Promoting Biblical Exceptionalism to Naturalize an Evangelical America. In Christian Tourist Attractions, Mythmaking, and Identity Formation. Edited by Erin Roberts and Jennifer Eyl. London: Bloomsbury, pp. 25-42. ISBN 978-1-350-16469-7.

Publisher's Note: MDPI stays neutral with regard to jurisdictional claims in published maps and institutional affiliations.

(C) 2020 by the author. Licensee MDPI, Basel, Switzerland. This article is an open access article distributed under the terms and conditions of the Creative Commons Attribution (CC BY) license (http://creativecommons.org/licenses/by/4.0/). 